\title{
The Occurrence of the Plantaris Muscle and its Muscle-Tendon Relationship in Adult Human Cadavers
}

\author{
Presencia de Músculos Plantares y su Relación Musculotendinosa en Cadáveres Humanos Adultos \\ "José Aderval Aragão; **Francisco Prado Reis; ${ }^{* * *}$ Danilo Ribeiro Guerra \& ${ }^{* * * *}$ Richard Halti Cabral
}

\begin{abstract}
ARAGÃO, J. A.; REIS, F. P.; GUERRA, D. R. \& CABRAL, R. H. The occurrence of the plantaris muscle and its muscle-tendon relationship in adult human cadavers. Int. J. Morphol., 28(1):255-258, 2010.

SUMMARY: Twenty legs from adult male cadavers were examined to analyze the anatomical relationships between the component parts of the plantaris muscle. This muscle was present in all of the cadavers and it was found that the length of the muscle in relation to its belly was approximately three times greater than in relation to the tendon.
\end{abstract}

KEY WORDS: Plantaris muscle; Anatomy.

\section{INTRODUCTION}

The plantaris muscle is a small muscle with a short belly and long thin tendon that forms part of the posterior superficial compartment of the leg, together with the soleus and gastrocnemius muscles (Moore, 2001). From an anatomical point of view, it is a fusiform muscle in which the muscle belly occupies a length of 5 to $10 \mathrm{~cm}$ (Hollinshead, 1980). Simpson et al. (1991) believed that the plantaris muscle was an accessory muscle and only vestigial in humans, and that it might be absent in 7 to $20 \%$ of individuals. According to Cruveilhier (1834), this muscle has little importance in leg movements. They compared it with the palmaris longus muscle of the forearm. The plantaris muscle, just like the psoas minor muscle in humans, may sometimes be absent (Testut, L. \& Latarjet, 1977; Gardner et al., 1988) or appear in duplicate (Goss \& Gray, 1988; Rana et al., 2006). Daseler \& Anson (1943) highlighted the importance of knowledge of the plantaris muscle from the phylogenetic and anatomical points of view. While performing surgery on patients with feet presenting congenital equinovarus or fixed equinovarus deformity, Osny et al. (1994) observed that the plantaris muscle was present in all cases. These authors attributed the etiology of these cases to the presence of an accessory soleus muscle.
Platt (1931), Miller (1977), Severance \& Basset (1982) and Mennen (1983) reported that there had been much controversy regarding lesions of the plantaris muscle. They emphasized that these lesions were of fundamental importance for the differential diagnosis of pain originating in the proximal region of the calf.

The so-called tennis leg condition, characterized by calf muscle or tendon injury has given rise to much controversy in the literature (Platt; Mennen). According to Delgado et al. (2002), tennis leg is a relatively common clinical condition. They also reported that rupture at the muscle-tendon boundary of the muscle during abrupt contraction movements of the posterior leg muscles have great clinical importance not only among tennis players but also among basketball players and sprinters.

The development and use of imaging diagnostic methods has enabled increasing use of the tendon of the plantaris muscle for reconstruction of hand tendons and lateral ankle ligaments and for repairs on atrioventricular valves (Palladino et al., 1991; Helms et al., 1995; Shuhaiber \& Shuhaiber, 2003; Pagenstert et al., 2006; Spina, 2007).

\footnotetext{
* Adjunct Professor of Human Anatomy in the Federal University of Sergipe (UFS) and Medicine Faculty of the Tiradentes University (UNIT), Aracaju, Sergipe, Brazil.

** Titular Professor Medicine Faculty of the Tiradentes University (UNIT), Aracaju, Sergipe, Brazil.

${ }^{* * * *}$ Adjunct Professor of Human Anatomy in the Federal University of Sergipe, Aracaju, Sergipe, Brazil.

${ }^{* * * * *}$ Assistent Professor in the University of São Paulo (USP), São Paulo, Brazil.
} 
The aim of the present study was to observe the frequency of presence of the plantar muscle and the relationships between its muscle and tendon parts.

\section{MATERIAL AND METHOD}

Twenty legs from ten adult male cadavers were dissected, of which ten were right legs and ten were left legs. The apparent age of the cadavers was between 40 and 68 years, and they had been fixed and stored in 10\% formol solution for more than one year. The cadavers belonged to the Anatomy Laboratory of the Federal University of Sergipe. The material was used in accordance with Law 8501, of November 30, 1992, which provides rules for the use of non-reclaimed cadavers for study or scientific research purposes. Cadavers that presented pathological abnormalities in the legs that were macroscopically detectable were excluded. The observations resulting from the anatomical dissection were documented by means of digital photographs, and measurements were made using a digital pachymeter.

\section{RESULTS}

The plantaris muscle was present in all of the cadavers dissected. Its muscle bundles were oriented laterallymedially (Fig. 1a) or convergently towards the tendon (Fig. 1b). Its proximal insertion was into the lateral supracondylar line of the femur, superiorly and medially to the head of the gastrocnemius muscle. Its tendon passed obliquely downwards between the gastrocnemius and soleus to insert into the medial face of the calcaneus. The mean length of tendon extending into the muscle was $5.5 \mathrm{~cm}$, and the tendon had a mean width of $0.7 \mathrm{~cm}$ in the belly of the muscle.

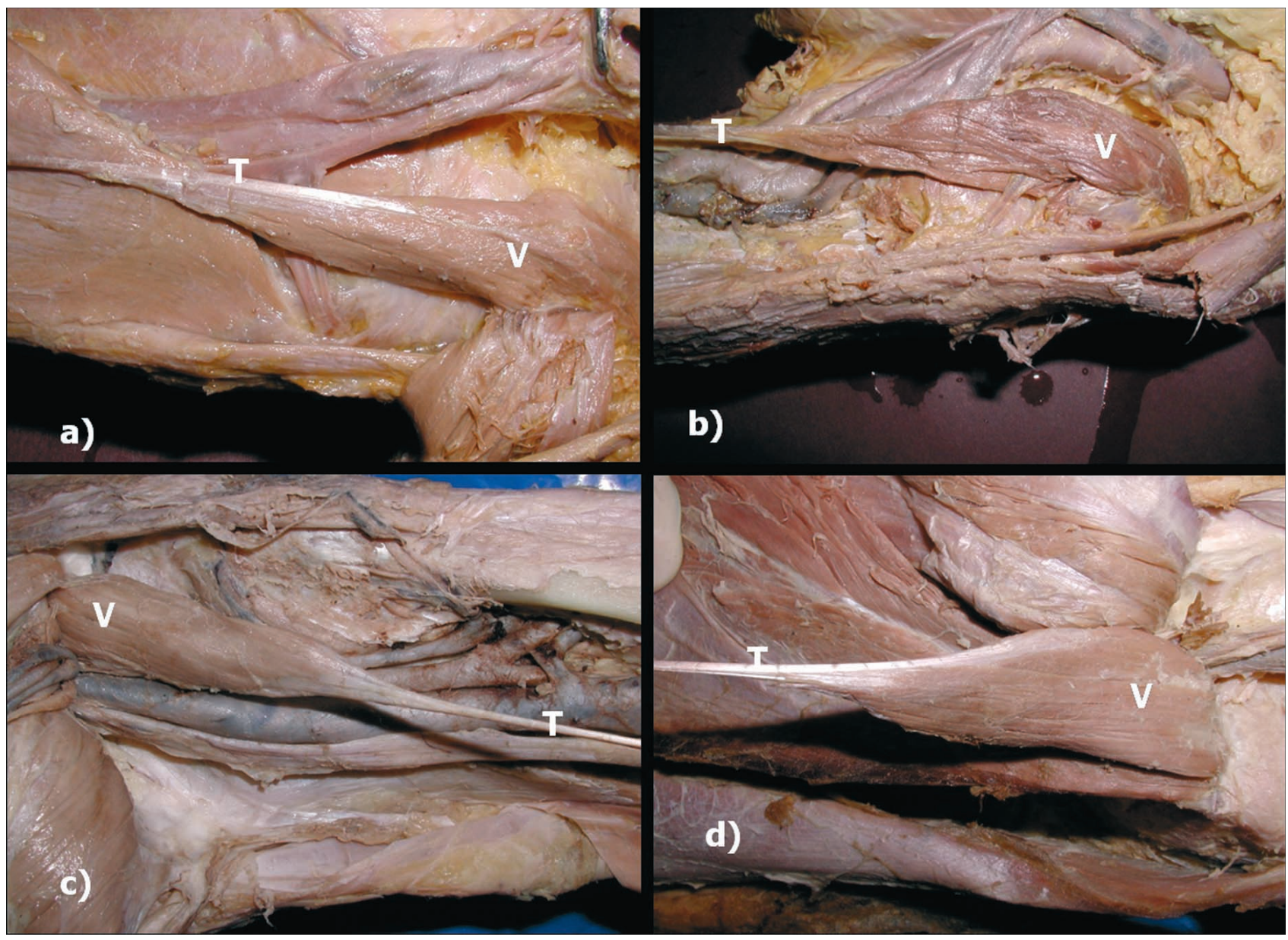

Fig. 1. Plantaris muscle. a) Muscle bundles inserting laterally into the tendon. b) Muscle bundles converging on the tendon. c) Dorsal view of the insertion of the muscle bundles into the tendon. d) Ventral view of the insertion of the muscle bundles into the tendon. $\mathrm{T}=$ tendon, $\mathrm{V}=$ =muscle belly. 
The dorsal bundles of the belly of the muscle were inserted laterally into the tendon (Fig. 1c), while the ventral bundles seemed to converge towards the medial region of the tendon (Fig. 1d). At the level of the muscle/tendon transition, it was observed that the tendon extended along the entire lower third of the belly of the muscle. The mean length of the plantaris muscle from its proximal insertion to its distal insertion was $43.25 \mathrm{~cm}$. The mean lengths of the belly of the muscle and the tendon were 11.38 and $33.26 \mathrm{~cm}$ respectively. The muscle/tendon ratio was $1.3 \mathrm{~cm}$, muscle/ belly $3.8 \mathrm{~cm}$ and muscle belly/tendon $0.3 \mathrm{~cm}$.

\section{DISCUSSION}

The insertions of the plantaris muscle found in the present study were similar to those described in several anatomy textbooks (Moore; Hollinshead; Testut \& Latarjet; Gardner et al.) and specialized studies (Palladino et al.; Helms et al.; Shuhaiber \& Shuhaiber; Pagenstert et al.; Spina). Regarding the presence of the muscle, Testut \& Latarjet and Gardner et al. reported that it might be absent.
Daseler \& Anson dissected 750 legs and accepted that the rate of absence was $6.67 \%$. According to Simpson et al., this rate would be between 7 and $20 \%$ of the cases. Goss \& Gray and Rana et al. reported the presence of a double plantaris muscle, which we did not find in any of the cases we studied. In the present study, the plantaris muscle was present in all the cadavers dissected. This finding is similar to what was described by Osny et al. Regarding the length of the belly of the muscle, our results corroborated the findings of Hollinshead.

Through the present findings, the aim within our setting was to provide data on the anatomy of the plantaris muscle among human cadavers. Given the descriptions and comments in the literature, our hope was that these findings might help in clinical interpretations and imaging diagnostics for lesions of the plantaris muscle, and with regard to indications for its use in restorations on other tendons.

In conclusion, the morphology of the insertion of the muscle bundles is different on the ventral and dorsal faces of the plantaris muscle.

ARAGÃO, J. A.; REIS, F. P.; GUERRA, D. R. \& CABRAL, R. H. Presencia de músculos plantares y su relación musculotendinosa en cadáveres humanos adultos. Int. J. Morphol., 28(1):255-258, 2010.

RESUMEN: Se estudiaron 20 miembros inferiores de cadáveres de adultos do sexo masculino con el fin de analizar la relación anatómica de los músculos plantares y sus partes constitutivas. En todos las piezas estudiadas este músculo estaba presente y fue observado que la longitud del músculo en relación a su vientre era aproximadamente tres veces superior a la del tendón.

PALABRAS CLAVE: Musculo plantar; Anatomía.

\section{REFERENCES}

Cruveilhier, J. Anatomie descriptive. $1^{\mathrm{a}}$ Ed. Paris, Bechet Jeune, 1834. pp.262-3.

Daseler, E. H. \& Anson, B. J. The plantaris muscle: An Anatomical Study of 750 Specimens. J. Bone Joint Surg. Am., 25(4):822-7, 1943.

Delgado, G. J.; Chung, C. B.; Lektrakul, N.; Azocar, P.; Botte, M. J.; Coria, D.; Bosch, E. \& Resnick, D. Tennis leg: clinical US study of 141 patients and anatomic investigation of four cadavers with MR imaging and US. Radiology, 224(1):112-9, 2002.

Gardner, E.; Gray, D. J. \& O'Rahilly, R. Anatomia. 4ª Ed. Rio de Janeiro, Guanabara Koogan, 1988. p.227.

Goss, C. M. \& Gray, H. Anatomia. $2^{\mathrm{a}}$ Ed. Rio de janeiro, Guanabara Koogan, 1988. pp.800-59.
Helms, C. A.; Fritz, R. C. \& Garvin, G. J. Plantaris muscle injury: evaluation with MR imaging. Radiology, 195(1):201-3, 1995.

Hollinshead, W. H. Livro texto de anatomia. $3^{\text {a }}$ Ed. São Paulo, Harper \& Row do Brasil, 1980. p.456.

Mennen, U. Rupture of the plantaris - does it exist? J. Bone Joint Surg. Am., 65(7):1030, 1983.

Miller, W. A. Rupture of the musculotendinous juncture of the medial head of the gastrocnemius muscle. Am. J. Sports Med., 5(5):191-3, 1977.

Moore, K. L. Anatomia orientada para a clínica. $4^{\mathrm{a}}$ Ed. Rio de Janeiro, Guanabara Koogan, 2001. pp.519-21.

Osny, S.; Carvalho, Jr. A. E.; Fernandes, T. D.; Romano, D.; 
ARAGÃO, J. A.; REIS, F. P.; GUERRA, D. R. \& CABRAL, R. H. The occurrence of the plantaris muscle and its muscle-tendon relationship in adult human cadavers. Int. J. Morphol., 28(1):255-258, 2010.

Adachi, P. P.; Neto, R. S. Músculo solear acessório: aspectos clínicos e achados cirúrgicos. Rev. Bras. Ortop., 29(4):251-55, 1994.

Pagenstert, G. I.; Hintermann, B. \& Knupp, M. Operative management of chronic ankle instability: plantaris graft. Foot Ankle Clin., 11(3):567-83, 2006.

Palladino, S. J.; Smith, S. B. \& Jackson, J. L. Plantaris tendon reconstruction of the lateral ankle ligaments. J. Foot Surg., 30(4):406-13, 1991.

Platt, H. Observations on some tendon ruptures. Br. Med. J., 1(3666):611-5, 1931.

Rana, K. K.; Srijit Das, S. \& Verma, R. Douple plantaris muscle: a cadaveric study with clinical importance. Int. J. Morphol., 24(3):495-98, 2006.

Severance, H. W. Jr. \& Bassett, F. H. 3rd. Rupture of the plantaris - does it exist? J. Bone Joint Surg. Am., 64(9):1387-8, 1982.

Shuhaiber, J. H. \& Shuhaiber, H. H. Plantaris tendon graft for atrioventricular valve repair: a novel hypothetical technique. Tex. Heart Inst. J., 30(1):42-4, 2003.

Simpson, S. L.; Hertzog, M. S. \& Barja, R. H. The plantaris tendon graft: an ultrasound study. J. Hand Surg., 16(4):708-11, 1991.

Spina, A. A. The plantaris muscle: anatomy, injury, imaging, and treatment. J. Can. Chiropr. Assoc., 51(3):158-65, 2007.

Testut, L. \& Latarjet, A. Tratado de anatomia humana. $3^{\mathrm{a}}$ Ed. Rio de Janeiro, Salvat, 1977. pp.1165-6.
Correspondence to: José Aderval Aragão Rua Aloisio Campos 500, Bairro Atalaia CEP: 49035-020

Aracaju, Sergipe Brazil

Tel: 79-9989-6767

Email: jaafelipe@infonet.com.br

Received: 18-02-2010

Accepted: 11-03-2010 